\title{
Research on Teaching Practice of Literature Review Writing for Higher Vocational Undergraduates
}

\author{
Yongliang Xie \\ Logistics and Supply Chain Management School,Zhejiang Technical Institute of Economics \\ 66 Xue Zheng Street,Hangzhou,310018, Zhejiang, China \\ E-mail of the corresponding author: 564059974@qq.com
}

\begin{abstract}
This paper is a teaching summary of the literature review writing course which is integrated into the literature review course framework and oriented to higher vocational undergraduates. The basic steps of literature review writing are introduced through example teaching, and the structure and organization characteristics of different literature reviews and writing details such as common traps to avoid and commonly used beautiful words and sentences are shown.Special emphasis is placed on the use of appropriate scaffolding in the teaching process to help students with different ability levels master the writing skills of literature review. According to the feedback after class, most students have mastered the essentials of literature review writing and realized the significance of literature review writing, whether it is short-term academic research or work.Individual students can consciously find problems in work and seek help from others to complete improvement.The results showed that the students understood and mastered the writing skills of literature review, which laid a good foundation for further study and work.
\end{abstract}

Keywords:literature review writing,matrix analysis,instructional scaffolding,mind map

DOI: $10.7176 / \mathrm{JEP} / 12-27-02$

Publication date:September $30^{\text {th }} 2021$

The research is financed supported by "13th Five-Year Plan" Zhejiang Province Higher Education Reform Research Project "Research and Practice of Improving the Literature Reading Ability of Students majoring in Logistics Management of Higher Vocational Education at Different Levels" (JG20180779).

\section{Introduction}

Literature Reviews writing is a common assignment in four-year university courses,Junior College courses, and graduate education(Ridley, 2008), which also is an important genre (Cooper, 1988).Our research group divided the literature review process (Machi, L. A., \& McEvoy, B. T., 2009) into two stages (Yongliang Xie, 2021) : reading and writing, according to the learning needs of vocational college students with different academic systems.Based on the literature reading course (Yongliang Xie, 2021), Our research team members' experience in teaching the literature review writing course for higher vocational undergraduates is presented in this paper.This course is organized according to the cognitive route of "What-Why-How to write-How to avoid Traps". It mainly introduces how to carry out literature review writing, including the establishment of concept matrix, the structure and organization of general papers, and the common vocabulary and sentences of applied academic empirical journal papers,selection of instructional scaffolding tool and some common mistakes to be avoided in writing.

\section{Literature review writing process}

2.1 Create thematically based concept matrix

Concept matrix is a systematic and objective method for literature review writing,which is a very useful explanatory tool to help researchers clarify their research priorities.A unit of symbols arranged in rows and columns forms a symbol set for use as a data set, allowing researchers to draw conclusions about the relationships between entries in a table.Basically, matrices contain the research information that explains various aspects of the research and allows researchers to quickly outline data and information relevant to a point.Common matrix forms are Table 1 and Table 2, with differences in the degree of subdivision of column entries. 
Table 1 Thematically Based concept matrix style one

\begin{tabular}{|l|l|l|l|l|l|l|l|l|l|l|}
\hline & $\begin{array}{l}\text { Main } \\
\text { viewpoint }\end{array}$ & $\begin{array}{l}\text { Article } \\
\text { purpose }\end{array}$ & $\begin{array}{l}\text { Research } \\
\text { Question }\end{array}$ & $\begin{array}{l}\text { Why } \\
\text { important }\end{array}$ & Theory & $\begin{array}{l}\text { Sample } \\
\text { method } \\
\text { /size } \\
\text { /data info }\end{array}$ & $\begin{array}{l}\text { Key } \\
\text { Definitions }\end{array}$ & $\begin{array}{l}\text { Analytic } \\
\text { Technique }\end{array}$ & $\begin{array}{l}\text { Key } \\
\text { Findings }\end{array}$ & $\begin{array}{l}\text { Additional } \\
\text { Key } \\
\text { Themes }\end{array}$ \\
\hline $\begin{array}{l}\text { Source } \\
1\end{array}$ & & & & & & & & & & \\
\hline $\begin{array}{l}\text { Source } \\
2\end{array}$ & & & & & & & & & & \\
\hline $\begin{array}{l}\text { Source } \\
3\end{array}$ & & & & & & & & & & \\
\hline$\ldots$
\end{tabular}

or

Table 2 Thematically Based concept matrix style two

\begin{tabular}{|c|c|c|c|c|c|c|c|}
\hline $\begin{array}{l}\text { Author/ } \\
\text { Date }\end{array}$ & $\begin{array}{l}\text { Theoretical/ } \\
\text { Conceptual } \\
\text { Framework }\end{array}$ & $\begin{array}{l}\text { Research } \\
\text { Question(s)/ } \\
\text { Hypotheses }\end{array}$ & Methodology & $\begin{array}{l}\text { Analysis } \\
\& \\
\text { Results }\end{array}$ & Conclusions & $\begin{array}{l}\text { Implications } \\
\text { for } \\
\text { Future } \\
\text { research }\end{array}$ & $\begin{array}{l}\text { Implications } \\
\text { For practice }\end{array}$ \\
\hline$\ldots$ & & & & & & & \\
\hline$\ldots$. & & & & & & & \\
\hline$\ldots$ & & & & & & & \\
\hline
\end{tabular}

The researchers generate the contents of the concept matrix by the aids of the abstracts and conclusions of the references. Once the appropriate literature has been found, this requires a critical analysis of each reference to identify potential approaches to the problem.In this way, the researchers systematically read each article, taking into account the validity of its content, and then classified it.The advantage of using this approach is that it allows the researchers to determine directly, at a glance, which articles cover a particular research topic, allowing researchers to identify, categorize, and evaluate facts unambiguously, rather than extrapolating indirectly from articles that are isolated from each other.

Of course, the construction of literature survey matrix varies greatly, and there is no unified standards and templates.How to construct a matrix is a process related to the individual creativity, proficiency and ingenuity of the researchers.At the same time, with the deepening of the understanding of the research topic, it is necessary to constantly modify the earlier version of the literature survey matrix.At the same time, the literature survey matrix has many forms (Sarantakos 1998), such as:

- Examples of publication dates (i.e., time series matrices) showing the longitudinal development of the subject are shown in Table 3 from Bhamu J., Sangwan K.S.(2014)

Table 3 Publication sequence of LEAN tools

Lean tools/techniques/ methodologies

VSM

Kanban/Pull

JIT

TPM
References

Hines et al. (1998, 1999), McDonald et al. (2002), Kalsaas (2002), Emiliani and Stec (2004), Huang and Liu (2005), Modarress et al (2005), Seth and Gupta (2005), Comm and Mathaisel (2005), Taylor (2005), Kumar et al (2006), Parry and Turner (2006), Weller et d. (2006), Worley and Doolen (2006), Braglia et al. (2006), Shen and Han (2006), Abdulmalek and Raigopal (2007), Weller et al. (2006), Worley and Doolen (2006), Braglia et al. (2006), Shen and Han (2006), Abdulmalek and Raigopal (2007),
Lander and Liker (2007), Lian and Landeghem (2007), Johansen and Walter (2007), Krishnamurthy and Yauch (2007), Seth Lander and Liker (2007), Lian and Landeghem (2007), Johansen and Walter (2007), Krishnamurthy and Yauch (2007), Seth
et al. (2008), Lasa et al. (2008), Sahooet al. (2008), Serranoet al. (2008), Grewal (2008), Wong et al. (2009), Braglia et al. (2009), Yu et al. (2009), Lasa et al. (2009), Boyle and Scherrer-Rathje (2009), Stump and Badurdeen (2012), Wee and Wu (2009), Alvarez et al. (2009), Puvanasvaran et al. (2009), Anand and Kodali (2009b), Dentz et al. (2009), Singh and Sharma (2009), Piercy and Rich (2009), Villa (2010), Rashid et al. (2010), Miller et al. (2010), Chen and Meng (2010a, b), Vinodh et al. (2010), Al-Ta hat (2010), Grove et al. (2011), Hodge et al. (2011), Yang and Lu (2011), Singh et al. (2011), Jiménez et al. (2011), Anand and Kodali (2011), Bhamu et al. 2013

Barker (1994), Sohal and Egglestone (1994), Karlsson and Àhlström (1996), Niepce and Molleman (1996), Hines et al. (1998), Pheng and Chuan (2001), McDorald et al. (2002), Naylor (2000), Wu (2003), Berry et al. (2003), Furterer and Elshennawy $(2005)$. Huang and Liu (2005), Taylor (2005), Conti et al. (2006), Weller et al. (2006), Worley and Doolen (2006), Taj and Ber ro (2006), Bonavia and Marin (2006), Braglia et al. (2006), Abdulmalek and Rajgopal (2007), Lander and Liker (2007), Lian and Landeghem (2007), Jensen and Jensen (2007), Shah and Ward (2007), Lasa et al. (2008), Serrano et al. (2008), Bayo-Moriones Landeghem (2007), Jensen and Jensen (2007), Shah and Ward (2007), Lasa et al. (2008), Ser rano et al. (2008), Bayo-Moriones
et al. (2008), Wong et al. (2009), Boyle and Scher rer-Rathje (2009), Puvanasvaran et al. (2009), Villa (2010), Rashid et al. et al. (2005), Wong et al. (2009), Boyle and Scher rer-Rathje (2009), Puvanasvaran et al. (2009), Villa (2011),
(2010), Perez et al (2010), Saurin et al. (2011), Pool et al. (2011), Hodge et al. (2011), Singh et al. (2011) .

Barker (1994), Prickett (1994), Sohal and Egglestone (1994), Boyer (1996), Forza (1996), Karlsson and Ȧhlström (1996), Katayama and Bennett (1996), Sohal (1996), Niepce and Molleman (1996), Storch and Lim (1999), White et al. (1999), Naybr (2000), Sanchez and Parez (2001), Gulyani (2001), Pheng and Chuan (2001), Yusuf and Adeleye (2002), Kalsaas (2002), Shah and Ward (2003), Wu (2003), Berry et al. (2003), Comm and Mathaisel (2005), Chen et al. (2005), Conti et al. (2006), Taj and Berro (2006), Abdulmalek and Raigopal (2007), Swamidass (2007), Shah and Ward (2007) Johansen and Walter (2007). Bayo-Moriones et al. (2008), Brown et al. (2008), Shah et al. (2008), Jayaram et al. (2008), Wong et al. (2009), Fullerton and Wempe (2009)

Katayama and Bennett (1996), Niepee and Molleman (1996), Hines et al. (1998), Shah and Ward (2003, 2007), Berry et al. (2003), Huang and Liu (2005), Conti et al. (2006), Kumar et al. (2006), Bonavia and Marin (2006), Abdulmalek and Rajgopal (2007), Black (2007), Sahoo et al. (2008), Wong et al. (2009), Boyle and Scher rer-Rathje (2009), Puvanasvaran et al. (2009), Villa (2010), Perez et al. (2010), Chen and Meng (2010b), Saurin et al. (2011), Hodge et al. (2011), Jiménez et al. (2011) 
- Sort by key people solving a specific problem (namely role order matrix),Example Table 4 comes from Bhamu J., Sangwan K.S. (2014).

Table 4 The history of the concept of LEAN

\begin{tabular}{|c|c|c|c|c|c|c|c|}
\hline Sl. no. & Author(s) & $\begin{array}{l}\text { Profile of } \\
\text { Author(s) }\end{array}$ & Country & Year & Contribution to research & Methodology & Type of industry \\
\hline 1. & Krafcik & A & USA & 1988 & $\begin{array}{l}\text { Introduces the term "Lean" in order to describe a } \\
\text { production system that uses less resources of } \\
\text { everything compared to mass production }\end{array}$ & Descriptive & - \\
\hline 2. & $\begin{array}{l}\text { Delbridge and } \\
\text { Oliver }\end{array}$ & $\mathrm{A}$ & UK & 1991 & $\begin{array}{l}\text { Analyze the application of lean in Japanese } \\
\text { automotive manufacturers and wide range of } \\
\text { performance gap between Western and Japanese } \\
\text { assembler through stock turnover data }\end{array}$ & Empirical & $\begin{array}{l}\text { Japanese and } \\
\text { Western automotive } \\
\text { industries }\end{array}$ \\
\hline 3. & Barber & $\mathrm{P}$ & UK & 1992 & $\begin{array}{l}\text { Provides improvements in quality, productivity, and } \\
\text { stock turns through lean implementation in an } \\
\text { automotive industry }\end{array}$ & $\begin{array}{l}\text { Exploratory } \\
\text { longitudinal }\end{array}$ & $\begin{array}{l}\text { Automotive } \\
\text { industry }\end{array}$ \\
\hline 4. & Badham & $\mathrm{A}$ & Australia & 1992 & $\begin{array}{l}\text { Provides an outline of the positive European } \\
\text { challenge to lean production models and their } \\
\text { implications for global manufacturing }\end{array}$ & Descriptive & - \\
\hline 5. & Ellegard $e t a l$. & $\mathrm{AP}$ & Sweden & 1992 & $\begin{array}{l}\text { Empirical analysis of mass, lean, and reflective } \\
\text { production system in Swedish automotive assembly } \\
\text { industry }\end{array}$ & Empirical & $\begin{array}{l}\text { Automotive } \\
\text { industry }\end{array}$ \\
\hline 6. & $\begin{array}{l}\text { Jacobs and } \\
\text { Meerkov }\end{array}$ & $\mathrm{AP}$ & USA & 1993 & $\begin{array}{l}\text { Analyze the due-time performance index in lean and } \\
\text { mass mamufacturing environments }\end{array}$ & Conceptual & - \\
\hline 7. & Frank and Kiupel & $\mathrm{A}$ & Germany & 1993 & $\begin{array}{l}\text { Discusses the process supervision of a larm system, } \\
\text { based on fuzzy logic in lean production to reduce the } \\
\text { redundancy in the decision making }\end{array}$ & Conceptual & - \\
\hline 8. & Berggren & $\mathrm{A}$ & Sweden & 1993 & $\begin{array}{l}\text { Discusses the lean production developments in the } \\
\text { auto industry and states that lean production is } \\
\text { certainly not the ultimate station of industrial } \\
\text { development }\end{array}$ & Descriptive & - \\
\hline 9. & Wickens & $\mathrm{P}$ & UK & 1993 & $\begin{array}{l}\text { Discusses the lean production system, its critics and } \\
\text { the future }\end{array}$ & Descriptive & - \\
\hline 10. & Barker & A & UK & 1994 & $\begin{array}{l}\text { Total time-based value added analysis which aids } \\
\text { the design of lean manufacturing systems }\end{array}$ & $\begin{array}{l}\text { Exploratory } \\
\text { longitudinal }\end{array}$ & $\begin{array}{l}\text { Electrical } \\
\text { switchgear }\end{array}$ \\
\hline
\end{tabular}

- Consolidation of composite index or ratio data so that several components of a single variable are organized (i.e., list matrix).

- The central theme (namely concept matrix),Example Table 5 comes from Ranjan B (2010). Table 5 Prediction methods for reducing bullwhip effect

\begin{tabular}{ll}
\hline Forecasting method & Contributors \\
\hline MA & $\begin{array}{r}\text { Sun and Ren [16], Chen et al. [42], Muth [45], Goodman [46], Graves [47], } \\
\text { Reiner and Fichtinger [50] } \\
\text { ES }\end{array}$ \\
Bayraktar et al. [3], Sun and Ren [16], Chen et al. [44]. \\
Sun and Ren [16], Alwan et al. [49]. \\
AR & Lee et al. [19, 28], Chen et al. [42], and Hosoda and Disney [43]. \\
ARIMA & Chen and Disney [52], Gaalman and Disney [53] \\
Regression model & Reiner and Fichtinger [50] \\
Kalman Filter & Sima et al. [51]
\end{tabular}

- Results and Dependent Variables (namely Effect Matrix).

- Participates in a process and results by exposing the dynamics of a particular environment (namely Field Dynamics Matrix).

- Screens a sequence of events in any possible order(namely Events Listing) .

- Debunking the causal relationship between dependent and independent variables (namely Causal Network). In short, critical reading a concept matrix is a great way to rigorously evaluate each piece of article.

2.2 Identify literature review types and decide organizational methods

Only after taking matrix analysis notes while reading the literature will you have a general view of the material and decide whether to make a small or large review.Some journals now tend to publish short reviews focusing on the past few years by limiting the number of words and references, which has the advantage of reducing the burden for those busy readers, but has the disadvantage of simplifying some questions and leaving out relevant material due to space constraints. While a large review has the advantage of covering the complexities of particular scientific developments in free and detailed detail, it has the disadvantage of leaving a pile of very important papers for readers who don't have time to read.

In addition, literature reviews can be descriptive or systematic.Descriptive reviews focus on the methods, findings, and interpretations of each study and are mostly qualitative, while systematic reviews attempt to find common ideas and concepts from the material, and many have quantitative analyses (Khoo CSG, 2011;Cook DA, 
2012).A systematic review becomes a meta-analysis when it analyzes qualitative results in a quantitative way.Systematic review itself is a research method. The literature search process is more rigorous and comprehensive. The search criteria must be clearly stated to avoid bias as much as possible, and transparent criteria should be used to extract and evaluate research data.Obviously for the average college student, descriptive review is more suitable for learning practice, because it is much less difficult.

Different types of reviews must be selected on a case-by-case basis, depending not only on the nature of the material found and the preferences of the target journal (if published at all), but also on when the review was written and the number of co-authors (Dijkers M,2009).

In the teaching process, each student must understand that the most important characteristics of a good review are clarity, originality, insight and analysis.Students are expected to choose sources fairly and critically compare these ideas and evidence to determine what still needs to be known and researched (see Table 6).

Table 6 The specific contents of a good overview

\begin{tabular}{|c|c|}
\hline Research object & Representative questions \\
\hline solve the problem & $\begin{array}{l}\text { - What is the cause of the problem for progress? } \\
\text { - What new technologies or approaches can be tried? } \\
\text { - Why are these new technologies or methods better than existing ones? } \\
\text { - Is there a new understanding of the cause of the problem, meaning a new approach? } \\
\text { - Are there other ways to conceptualize problems that might lead to new and better ways } \\
\text { of solving problems? }\end{array}$ \\
\hline $\begin{array}{l}\text { Fill in the gaps in } \\
\text { understanding }\end{array}$ & $\begin{array}{l}\text { What theory can guide: } \\
\text { - Where to find the answer? } \\
\text { - How to explain the survey results? } \\
\text { - How to it be analyzed? } \\
\text { - Which flaws in the current theory to be pointed out as much as possible? }\end{array}$ \\
\hline Evaluate something & $\begin{array}{l}\text { - What standards are used and why? } \\
\text { - How are these standards implemented? } \\
\text { - What baseline judgment is good/satisfactory/poor? }\end{array}$ \\
\hline Improve something & $\begin{array}{l}\text { - What are the benefits/costs of improving/not improving? } \\
\text { - Which aspects are the most unsatisfactory? What is the most likely to lead to significant } \\
\text { improvement and why? } \\
\text { - Why doesn't this thing work the way it's supposed to? }\end{array}$ \\
\hline $\begin{array}{l}\text { Resolve conflicts in } \\
\text { the literature }\end{array}$ & $\begin{array}{l}\text { - What are the arguments for and against?This may be due to different schools of } \\
\text { research on issues with different theoretical foundations, or there may be differences in } \\
\text { assumptions that may need to be studied more carefully. } \\
\text { - What is required for disputing resolution? }\end{array}$ \\
\hline $\begin{array}{l}\text { Helpful to trace } \\
\text { others' research }\end{array}$ & - Clear, accurate and complete references to previous work. \\
\hline
\end{tabular}

The next step is to define the organizing principles for literature review.Common organizational structure methods include Theme, Chronology and Methodology. The most ones are the first two.Organizing methods by topic should identify and describe the major elements of a particular topic.In classroom, the teacher shared the writing structure of the work with the students by summarizing the causes of bullwhip effect (Ranjan B. \& Susmita B., 2010).

Example:A review of the causes of bullwhip effect in a supply chain

1 Introduction

2 Causes of bullwhip effect

3 Operational causes of bullwhip effect

3.1 Effect of forecasting

3.1.1 Time series modeling

3.1.2 Machine learning modeling

3.1.3 Agent-based modeling

3.2 Effect of ordering policy and batching

3.3 Effect of inventory policies

3.4 Effect of lead time

3.5 Effect of lack of transparency

3.6 Effect of replenishment policies

3.7 Effect of price fluctuation

3.8 Rationing and shortage gaming

3.9 Miscellaneous operational causes 
4 Effect of human behavior

4.1 Neglecting time delays in making ordering decisions

4.2 Lack of learning and/or training

4.3 Fear of empty stock

5 Mitigation of bullwhip effect(BWE)

5.1 Mitigation of $B W E$ as proposed in the existing literature

5.2 Mitigation of BWE in industry

6 Conclusion and further research issues

Chronology primarily identifies the changes on a topic over time, including the changes in understanding, methodological or theoretical development.This is often related to the purpose of the research.If the literature review is organized chronologically, it is common to have a section on basic methods/tools, followed by a section on advanced methods, followed by a discussion on using the most advanced tools to focus on current understanding.Presented in this way, the reader can see how understanding of the field has matured over time.Taking Ronald H. Ballou's The Evolution and Future of Logistics and Supply Chain Management (2007) as an example (Figure 1), literature review organized by chronology from a single function before the early 1950s to material procurement and to management in the $1960 \mathrm{~s}$, physical distribution in the $1980 \mathrm{~s}$, and then to logistics before 2000 and to supply chain management after 2000, the corresponding organizational structure has changed (Figure 2). Finally, the core themes of supply chain management are predicted:

(a)A revenue generation strategy for the supply chain will be as important as a cost reduction one.

(b)Boundary-spanning benefits of SCM may be easy to identify but will be hard to realize.

(c) Coordination and collaboration, along with trust, are the most important elements to realizing boundaryspanning opportunities.

(d)Information sharing among channel members is likely to continue with advancing technology and may be called coordination, compromise, and cooperation.

(e)Boundary-spanning metrics will be needed to identify supply chain benefits and track their location in the supply channel.

(f)Methods of benefits sharing need better definition and refinement.

(g)Supply chain relationships are not inherently steady-state, so examples of good supply chain coordination among a few firms will be selective and short term.

(h)Logistics curricula transforming to a supply chain curricula which expanded to the build-relationship.

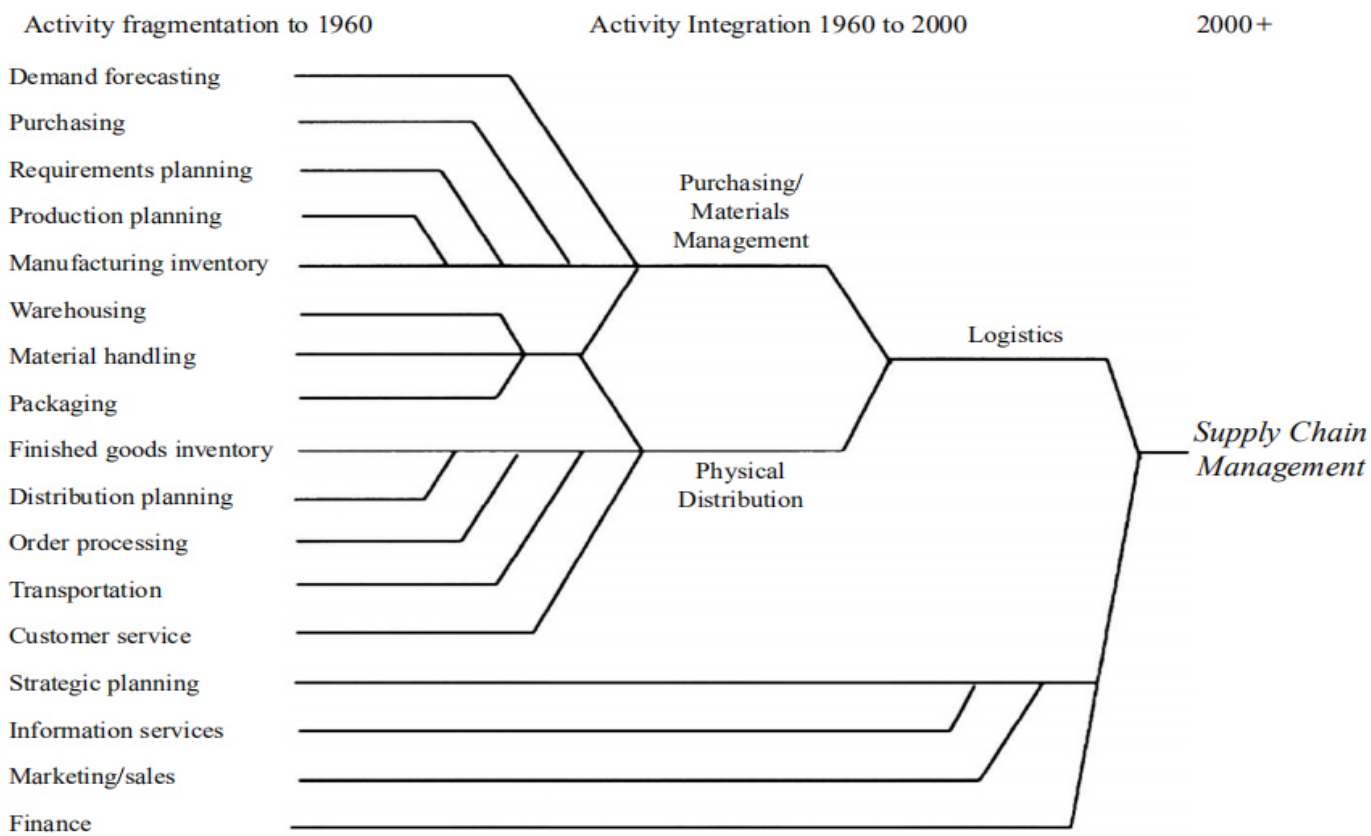

Figure1 The evolution and future of logistics and supply chain management 

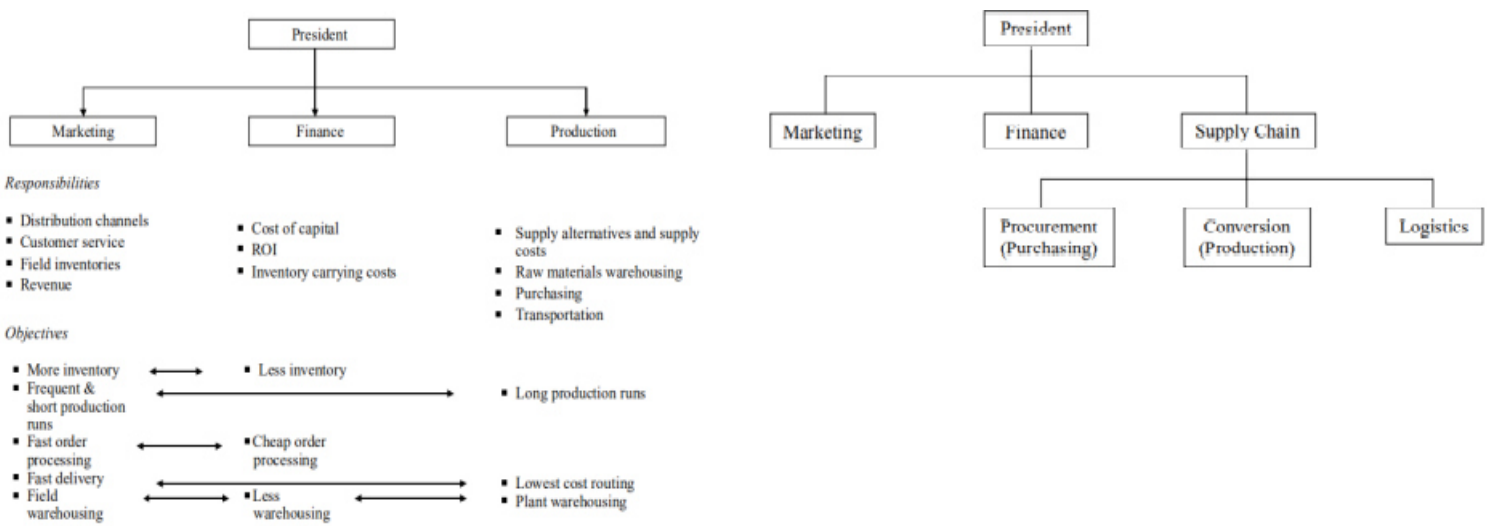

Figure 2 The change of organization structure

It can be challenging to organize the body of a review article to attract readers.It is often helpful to use mind mapping techniques to create a conceptual scheme for a review,can help identify the sequence and link the parts of the review (Ridley D, 2008).Careful selection of charts and figures related to the topic of the review is also helpful for text structure, and an overall plan can generally be determined by mind mapping:

STEP1: Start developing a clear and complete statement of the research problem and place the theme or central question in the middle of the page.

STEP2: List the final topic/central problem/key term/concept/phrase to be addressed, in any order.Note that a subtopic that always needs to be addressed is: "Why is this question /interesting /important?"It is often helpful to think about the key issue rather than the subject matter.

STEP3: The next key point/instance/theory to be solved under each sub-topic, such as the significance of the research field and the gap/deficiency of existing knowledge,sources/assumptions of new ideas, theoretical guidance on where to look for answers.

STEP4: Look for subsequent subtopics/problems that will be approaches to current solutions and links between subtopics.

STEP5: Once the mind map is complete, numbers that show the logical order to determine the logical order of writing can be added.

D. R. Rowland (2010) provided a generic mind map for a very valuable literature review (see Figure 3).

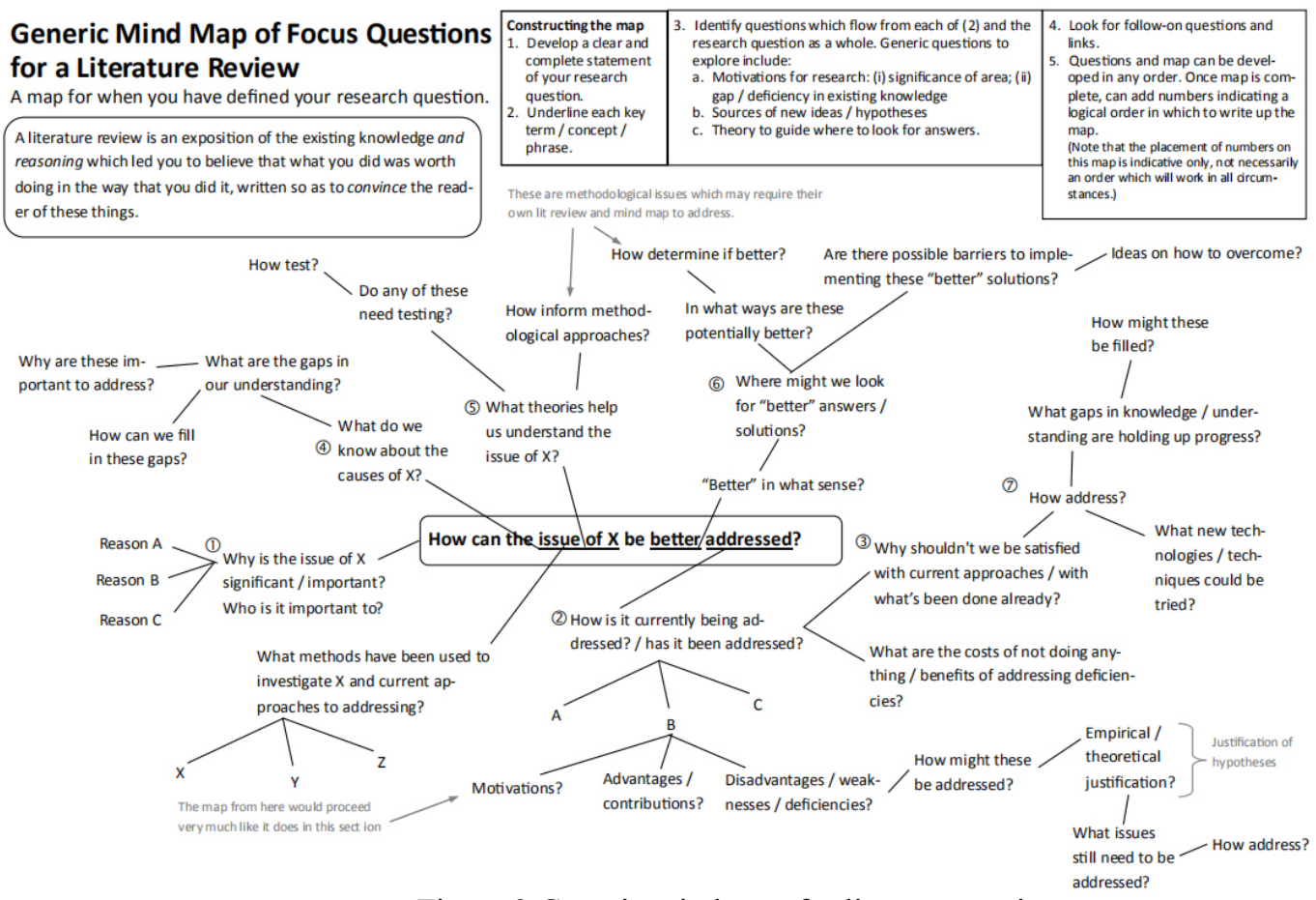

Figure 3 Generic mind map for literature review

2.3 MEAL based writing strategies and critical writing vocabulary selection

The next concern is how to write, namely writing strategy.The teachers borrowed MEAL (Arlene Fink, 2019), which is an effective writing strategy,is very useful and often widely and easily used by researchers. 
M signifies main point, which describes the overall status or quality of the literature.generally the first sentence of each section should be the main point of the section.

E indicates evidence. The main idea is supported by the evidence.Often directly quoted or relayed in the form of information from the original source material.

A denotes analysis.Identify stripped information from sections after presenting evidence.This message may focus on missing areas and generally give the most important information to the reader in one sentence.

L represents linkage which occurs in two ways.First, it refers to including a kind of statement that connects the chapter to the focus of the review.Second, it refers to switching between parts. Linkage ensures a passage flows from one section to another so that the literature review is cohesive.

Take one fragment of Ronald H. 's article(2007) as an example to illustrate the use of MEAL (see Figure 4).

The future

Understanding the past and observing the present allows an extrapolation to what might be in store for logistics/SCM in the future. The trend toward increased globalization, free trade, and outsourcing all contribute to a continued and growing interest in logistics/SCM. According to a McKinsey \& Company study:

$\ldots$ by the year 2020,80 percent of the goods in the world will be manufactured in a country different from where they are consumed compared with 20 percent now.

There will be a tremendous shift in the movement and consumption of goods, all of which will require ever better management of the associated supply chain processes. There will be a shift in strategy. In the past, the focus of logistics/SCM has been on efficiency. As Drucker (1962) put it, physical distribution is: "The last frontier of cost economies".

The contemporary view is that SCM is a new frontier for demand generation - a competitive weapon. Both views will be important but the new emphasis will be on designing and operating the supply chain to enhance the revenues of the firm in such a way as to maximize contribution to profit This view replaces the often-used strategic obiective of minimizing supply chain costs subiect to meeting given customer service requirements and it will elevate SCM in the eves of top management. A new objective will emerge to capture revenue enhancement effects, which is called ROSCA. The object of ROSCA is to maximize return on supply chain assets. It is defined as:

Figure 4 The case of MEAL method

Students need to be reminded that the usage of MEAL does not need to be too rigid, changing the components as needed, for example,M-E,M-E,A,L is a common strategy.

Another key point of writing is the accurate use of vocabulary and sentences (John Morley,2014)(see Table 7), which is one of the core contents of teaching for students in traditional Chinese universities, especially lacking, because teachers take it for granted that students have mastered the expression of academic language after years of preliminary learning.In fact, on the contrary, inflexible secondary education leads to the inadequacy of fundamental learning skills.

Table 7 Commonly used words and sentences in literature review

\begin{tabular}{|l|l|l|}
\hline \multicolumn{1}{|c|}{ Intention } & \multicolumn{1}{|c|}{ Useful words(W) and sentences(S) } \\
\hline Draw a conclusion: & $\mathrm{S}$ & $\begin{array}{l}\text { Therefore, consequently, thus, hence ... } \\
\text { This section has reviewed the three key aspects of .... } \\
\text { This chapter has described the methods used in this investigation and it } \\
\text { has .... } \\
\text { In this section, it has been explained that ....The chapter that follows moves } \\
\text { on to consider the.... } \\
\ldots .\end{array}$ \\
\hline Justify/explain: & $\mathrm{W}$ & $\begin{array}{l}\text { Because, since, owing to,because of,as a result of,as a consequence of,may } \\
\text { cause,can lead to,can result in,caused by,resulting from, stemming } \\
\text { from,Therefore,Consequently,Because of this,As a result (of } \\
\text { this),thus,thereby.... }\end{array}$ \\
\cline { 2 - 4 } & $\mathrm{S}$ & $\begin{array}{l}\text { The causes of X have been the subject of intense debate within ..... } \\
\text { Another reason why Xs have declined is that .... } \\
\text { X and Y are important driving factors of Z. } \\
\text { As a consequence of X , it appears that Y alone is not the causative factor } \\
\text { of.... } \\
\ldots .\end{array}$ \\
\hline $\begin{array}{l}\text { Provide a contrasting or } \\
\text { opposing view: }\end{array}$ & W & $\begin{array}{l}\text { Although, however, while,whereas,compared with,By contrast, In } \\
\text { contrast,On the other hand,Unlike... }\end{array}$ \\
\hline
\end{tabular}




\begin{tabular}{|c|c|c|}
\hline & $\mathrm{S}$ & $\begin{array}{l}\mathrm{X} \text { is different from } \mathrm{Y} \text { in a number of respects. } \\
\mathrm{X} \text { differs from } \mathrm{Y} \text { in a number of important ways. } \\
\text { There are a number of important differences between } \mathrm{X} \text { and } \mathrm{Y} \text {. } \\
\text { Comparing the two results, it can be seen that .... } \\
\text { A comparison of the two results reveals .... } \\
\ldots .\end{array}$ \\
\hline \multirow{2}{*}{$\begin{array}{l}\text { Provide illustrative or } \\
\text { supporting evidence: }\end{array}$} & $\mathrm{W}$ & For example, such as, including... \\
\hline & $\mathrm{S}$ & $\begin{array}{l}\text { This is exemplified in the work undertaken by .... } \\
\text { Another example of what is meant by } \mathrm{X} \text { is .... } \\
\text { This is certainly true in the case of .... } \\
\text { This is evident in the case of .... } \\
\text { The evidence of } \mathrm{X} \text { can be clearly seen in the case of .... } \\
\ldots .\end{array}$ \\
\hline \multirow{2}{*}{$\begin{array}{l}\text { Make an additional } \\
\text { supporting point or provide } \\
\text { additional supporting } \\
\text { evidence: }\end{array}$} & $\mathrm{W}$ & In addition, moreover, furthermore, ... \\
\hline & $\mathrm{S}$ & $\begin{array}{l}\text { Overall, these cases support the view that .... } \\
\text { This case has shown that .... } \\
\text { This has been seen in the case of .... } \\
\text { The case reported here illustrates the .... } \\
\text { This case study confirms the importance of .... } \\
\text { The evidence presented thus far supports the idea that .... } \\
\ldots .\end{array}$ \\
\hline \multirow[t]{2}{*}{ Classifying and listing } & $\mathrm{W}$ & on the basis of,according to,depending on,in terms of .... \\
\hline & $\mathrm{S}$ & $\begin{array}{l}\text { This topic can best be treated under three headings: } \mathrm{X}, \mathrm{Y} \text { and } \mathrm{Z} \text {. } \\
\text { The key aspects of management can be listed as follows: } \mathrm{X}, \mathrm{Y} \text { and } \mathrm{Z} \text {. } \\
\text { The disadvantages of the new approach can be discussed under three } \\
\text { headings, which are: .... } \\
\ldots \text {... }\end{array}$ \\
\hline
\end{tabular}

2.4 Writing of the first draft

At this point, students have all the skills, strategies, and information for a literature review.After clearly identifying the main points and evidence (along with citations) of each topic, choose the organization of literature review, descriptive or systemic, and then organize the material according to MEAL method.Tell the students to focus on the overall structure and organization, not on each sentence.

\subsection{Edit, proofread, and polish repeatedly}

When the final literature review is repeatedly edited, proofread and polished, all elements should be carefully examined, such as main points, evidence, analysis, linkage, citations, etc.In addition to checking the fluency of the essay by reading it out aloud, ask peers to read and give feedback.Peers may find errors in logic and ambiguity, spelling mistakes and confusing sentences that author did not notice.Many students are afraid to share their review in classroom for fear that there are too many improvements to be made and they will feel depressed.

\subsection{Avoid common writing pitfalls}

(1)Not leaving enough time.Writing a literature review is time consuming, both looking up sources, reading, thinking and summarizing each article, and creating a summary matrix, and finally writing.

(2) Structure the literature review by focusing on the author rather than the subject and audience.Most commonly, students tend to combine a series of cited papers or simply focus on what the authors have said/done without articulating the relationships between the various sources.Finally, there is no way to synthesize and state their own views.

(3) An unsystematic or incomplete search of sources results in a review that may be too narrow, scattered or out of date.

(4)Lack of logical organization and structure.Many students are unaware of the characteristics of a good review, such as taking time to read, being timely, systematic, well written, focused, critical, well structured, and avoiding paragraph-to-paragraph summaries of a single work rather than a comprehensive analysis of all the materials.

(5)Unbalance the focus and breadth of the review.No matter what type of review you write, keep it focused and avoid simply piling up material.For a review of interdisciplinary intersections, the focus is on bridging the gaps between disciplines (Wagner CS, 2011).

(6) Not updating the results of older studies.Due to the rapid development of science and technology today, new papers related to the topic of the review will emerge in an endless stream. If a year and a half passes, it is 
necessary to search for new papers and update the review before completion to avoid being outdated.

(7) No criticism in writing. On the basis of critical discussion of the literature, identification of methodological problems, and pointing out the gaps between research (Carnwell R, 2001), a clear affirmation of the main achievements, major controversial areas and outstanding research issues in the field of review should be made.

(8) Make common writing mistakes.For example, do not use the word I in the literature review, because the literature review focuses on the content of the work.Similarly, the word "prove" should not be used either. In social science studies, nothing is ever proved.Another example is the choice between passive and active voice and present and past tense.Finally, avoid a lot of direct citations.

(9)Failure to demonstrate the need for the proposed research direction. The responsibility of the researcher is to make the reasons for research.

(10)Plagiarism and inaccurately or maliciously comments about other people's research.Students must bear in mind that it is unethical to simply copy other people's words as their own, and be wary of evaluating other people's research with clearly malicious vocabularies.

\section{Provide necessary scaffolding for writing instruction}

There is no doubt that students will encounter difficulties in the learning process, and it is necessary for teachers to provide corresponding support and feedback.According to Vygotsky's theory, learning skills can be divided into three types: those who can complete independently and cannot complete with the help of others, and those who can complete with the help of others (Dodge, 2002). When a student learns consumable skills with the help of others, known as an instructional scaffolding, he is in an ideal state of learning cognition, which Vygotsky calls the zone of proximal development (ZPD).

Clearly, the role of instructional scaffolding is to enhance students' existing abilities, focusing on particularly important and unsimplified task elements (Reiser,2004) for robust learning (Simons \& Ertmer, 2006),Helping students to have interest in learning tasks and maintain their participation (Belland,Kim,\& Hannafin,2013) ultimately enables students to acquire skills to complete tasks independently in the future, while at the same time students understand which indicators successful tasks mean (Mahardale \& Lee, 2013;Pea, 2004).Therefore, instructional scaffolding is an accidental event, and only after cyclic dynamic assessment of students' learning behavior characteristics can we decide whether to provide students with temporary support (Belland, 2014).

Vygotsky identified four stages of instructional scaffolding (Byrnes, 2001):

(1)Modeling and oral comments.Mainly used to describe what is the core steps of literature review, sample three to five different organizational structure of literature review, ask students to clear all the concepts and procedures. (2)Students imitate the skills demonstrated by the teacher, and the teachers continuously evaluate students' understanding and provide help and feedback frequently, but not for too long.Due to the amount of time required to write a complete literature review, it can be difficult to develop the required skills in a limited classroom.General the literature review practice are needed to develop some writing skills: the teachers in class firstly explain literature review writing skills and details, and then distribute student three journal articles with the same topic, such as research methods, together with the summary, let them read after, and ask them to finish by two to four paragraphs by applying the method of MEAL consisting of a small review.It is better for the teachers to show the words and sentences used in applied academic journals by induction (see Table 8).

Table 8 Common problems and possible scaffolding

\begin{tabular}{|l|l|}
\hline \multicolumn{1}{|c|}{ Common problem } & \multicolumn{1}{c|}{ Scaffolding that might be used } \\
\hline $\begin{array}{l}\text { Organize around authors, } \\
\text { not around the } \\
\text { topic/question } \\
\text { (e.g., list without synthesis) }\end{array}$ & $\begin{array}{l}\text { Use mind mapping to help organize material around general } \\
\text { topics/questions. Take notes under key questions rather than individually taking } \\
\text { notes from each article. }\end{array}$ \\
\hline $\begin{array}{l}\text { Lack of a clear } \\
\text { organizational structure }\end{array}$ & $\begin{array}{l}\text { Use mind mapping or lists of key issues to help organize, use descriptive } \\
\text { headings, sub-headings, appropriate links and landmarks to navigate the readers. }\end{array}$ \\
\hline $\begin{array}{l}\text { Indiscriminately dispose of } \\
\text { related and unrelated } \\
\text { materials }\end{array}$ & $\begin{array}{l}\text { Avoid collating only background information. } \\
\text { Understand the purpose of each section and do not provide information the reader } \\
\text { does not need. }\end{array}$ \\
\hline Not highlighted & $\begin{array}{l}\text { To show that there is a huge deficiency in the existing literature;Or have good } \\
\text { reason to believe that the assumptions are likely to be correct;And so on. }\end{array}$ \\
\hline Lack of landmark studies & $\begin{array}{l}\text { Landmark studies should be mentioned in the literature review, and use these as a } \\
\text { guide. }\end{array}$ \\
\hline Focus on outdated material & Be sure to keep track of the latest papers and cite them. \\
\hline Narrow point of view & Be sure to read widely, not just papers from one geographic location or field. \\
\hline
\end{tabular}

(3)The teachers began to remove the scaffolding.Teachers gradually reduce scaffolding as students begin to 
master the writing skills of literature review,ensuring that effective scaffolding instruction should always be at the ZPD level.

(4)Individual students reached a level of mastery without any help from their teachers.All concepts and procedures must be clear to students after practice.

Theory and practice showed that the necessary condition of instructional scaffolding method to achieve ideal results is correct execution.First, the scaffolding provided by teachers can improve students' understanding of the concept of literature review, but on the premise of well-organized content knowledge and positive transformation (Bransford et al., 2003).Second, students are provided with scaffolding, such as mind map, outline templates, note-taking guides and memory strategies, to help students develop skills that enable them to become self-directed and self-regulated learners.Finally, scaffolding can eliminate students' problems such as idleness and boredom (Byrnes, 2001).If the teachers adjust the teaching level to meet the students' recent development area, let the students' attention focus and be able to complete the task.

In the teaching of literature review writing, one-to-one scaffolding and peer scaffolding are the most commonly used scaffolds.One-to-one scaffolding is defined as a teacher in working with a student, dynamically assess the current level of students and provide the proper number of support, help the students in the target task execution and gain skills, and according to the need to customize support, until the scaffold can be completely removed and students can acquire skills ownership (Belland, 2014).In one-to-one scaffolding, the teachers are asked to think about what intentions are achieved through the scaffolding and the specific strategies used.One-toone scaffolding intentions include recruitment, construction tasks, maintenance direction, reduced freedom, and frustration control (Van de Pol et al., 2010).One-to-one scaffolding strategies include modeling, questioning, interpretation, prompting, and professional feedback (Van de Pol et al., 2010).On the one hand, one-to-one scaffolding can especially promote students' understanding and high level of performance (Levpušček, Zupanč I č, \& Sočan, 2013).One-to-one scaffolding, on the other hand, is limited in size and availability, as teachers cannot work one-to-one with all students in their classroom at the same time.But students can be encouraged to contact their teachers for help via instant messaging app after class.

Another scaffold is peer scaffolding, which refers to scaffolding supported by peers and balanced by the number of peers in the classroom (Davin \& Donato, 2013;Sabet, Tahriri, \& Pasand, 2013).Students with strong ability can improve students with poor ability through question and answer, demonstration and speech.But to prevent companions do not have enough patience to help poor students for a long time, and poor students are short of motivation to learn further.

The actual teaching experience shows that, on the one hand, in view of the different levels of students, teachers need to adopt composite scaffold, to ensure that the guidance on the recent development zone, excavate students' learning motivation to the greatest extent, on the other hand to prevent excessive guide, need to observe and evaluate students' behaviors, then give them the appropriate scaffolds and feedback. The objectives of literature review writing skills can be summarized as follows:

- Write an essay that clearly expresses their opinions on the studying topic.

- Practical research skills, including evaluating sources, relaying and summarizing relevant information, and quoting useful sources.

- Practice logically groups and ranks ideas in expository writing.

- Organize and display information in graphs, maps and charts.

\section{After-class survey results}

First of all, from the classroom feedback, one of the puzzles of students is the structure of literature review organization.Through step by step demonstration and practice, students gradually realized the importance of structure for literature review. In addition, they realized the beauty of words by trying to use different words and sentences to express the same meaning.

Secondly, one of the common characteristics of higher vocational students is that they are not confident enough in learning and dare not try. In most cases, they need teachers' supervision and timely guidance and encouragement to finish their homework.Multiple objective and appropriate difficulty task training, can well motivate students' study on the theme of the valuable, such as there are students in hangzhou hot couplet factory for apprenticeship learning found problems construction scaffolding leasing business, through Wechat with me to discuss the business of financial services and inventory management strategy design problem,and how to find relevant information in the enterprise.

Finally, studies have shown that literature review classes have a direct and long-term impact on students' reading and writing abilities. The students come out of the class more confident, when they understand what a literature review is and how to write it, they are often comfortable with it.Many students reported that they applied these strategies and skills of the literature review course to other courses as well. 


\section{Summary}

Literature review is the process by which the researchers analyze collected information about its structure, processes and relationships in some form, to increase familiarity with the research object and establish the credibility of the project research.At the same time, consider a comparative analysis of the previous study in relation to the current planned study, review the methodology and technical theory best suited to this study and assess their suitability and effectiveness (Sarantakos,1998).Therefore, literature review writing is an essential skill to measure students' professional learning quality, which is obviously inseparable from teachers' careful teaching and students' continuous training to accumulate writing experience and improve their writing ability through various feedback.However, because a complete literature review takes a lot of time, it is very difficult to develop all skills in the classroom.In general, there are small exercises in class to develop some literature review writing skills, and at the end of the semester all students are required to complete a large review of one topic, which is graded according to its quality.For teachers, teaching students how to write a good literature review not only requires patience and guidance, but also requires them to share their years of writing experience and details.Students who have taken this course generally understand the meaning of literature review and the general principles for organizing literature review structure, and can apply the skills in this course to other courses.This paper provides some valuable experience in the teaching practice of literature review writing for higher vocational undergraduates, which lays a foundation for further research on the structural equation among the factors affecting the reading effectiveness for higher vocational college students.

\section{References}

Arlene Fink(2019).Conducting Research Literature Reviews.SAGE Publications, Inc.

Belland, B. R., Kim, C., \& Hannafin, M. (2013). A framework for designing scaffolds that improve motivation and cognition. Educational Psychologist, 48(4), 243-270. http://doi.org/10.1080/00461520.2013.838920.

Belland, B. R. (2014). Scaffolding: Definition, current debates, and future directions. In J. M. Spector, In J. M. Spector, M. D. Merrill, J. Elen, \& M. J. Bishop (Eds.), Handbook of research on educational communications and technology (4th edn.), . New York: Springer. DOI: $10.1007 / 978-1-4614-3185-539$.

Bhamu J., Sangwan K.S. (2014).Lean manufacturing: literature review and research issues. International Journal of Operations \& Production Management, Vol. 34 Iss 7 pp. 876 - 940 http://dx.doi.org/10.1108/IJOPM-082012-0315

Bransford, J., Plants, B., \& Vye, N. (2003). Three AMIGO3s: Using “anchored modular inquiry" to help prepare future teachers. Educational Technology Research \& Development, 51(1), 105-123. http://doi.org/10.1007/BF02504521.

Byrnes, B. (2001). Cognitive Development and Learning in Instructional Contexts(Second Edition). Needham Heights, M.A:Allyn and Bacon.

Carnwell R, Daly W (2001). Strategies for the construction of a critical review of the literature.Nurse Educ Pract 1: 57-63. doi:10.1054/nepr.2001.0008.

Cook DA, West CP (2012) Conducting systematic reviews in medical education: a stepwise approach. Med Educ 46: 943-952. doi:10.1111/j.1365-2923.2012.04328.x.

Cooper, H. M. (1988). Organizing knowledge synthesis: A taxonomy of literature reviews. Knowledge in Society, $1,104-126$.

Davin, K. J., \& Donato, R. (2013). Student collaboration and teacher-directed classroom dynamic assessment: A complementary pairing. Foreign Language Annals, 46(1), 5-22. http://doi.org/10.1111/flan.12012.

Davis, M. and Morley J. (2018). Facilitating learning about academic phraseology: teaching activities for student writers, Journal of Learning Development in Higher Education, Special Edition: October 2018 ALDinHE Conference.

Dijkers M, The Task Force on Systematic Reviews and Guidelines (2009). The value of "traditional" reviews in the era of systematic reviewing. Am J Phys Med Rehabil 88: 423-430. doi:10.1097/PHM.0b013e31819c59c6.

Dodge, B. (2002). Schools, Skills and Scaffolding on the Web. 2nd. http://edweb.sdsu.edu/people/bdodge/scaffolding.html.

R. Rowland(2010), Reviewing the Literature: A Short Guide for Research Students, The University of Queensland. https://my.uq.edu.au/files/11020/guide-literature-review-research-students.pdf

Machi, L. A., \& McEvoy, B. T. (2009). The literature review: six steps to success. Thousand Oaks, Calif.: Corwin Press.

Mahardale, J. W., \& Lee, C. B. (2013). Understanding how social and epistemic scripts perpetuate intersubjectivity through patterns of interactions. Interactive Learning Environments,21(1),68-88. 
http://doi.org/10.1080/10494820.2010.547204.

M. D. Merrill, J. Elen, \& M. J. Bishop (Eds.), Handbook of research on educational communications and technology (4th edn). New York: Springer.

John Morley(2014).Academic Phrasebank. http://www.phrasebank.manchester.ac.uk/.

Khoo CSG, Na JC, Jaidka K (2011) Analysis of the macro-level discourse structure of literature reviews. Online Info Rev 35: 255-271. doi:10.1108/14684521111128032.

Levpušček, M. P., Zupančič, M., \& Sočan, G. (2013). Predicting achievement in mathematics in adolescent students: The role of individual and social factors. The Journal of Early Adolescence, 33(4), 523-551. http://doi.org/10.1177/0272431612450949.

Mahardale, J. W., \& Lee, C. B. (2013). Understanding how social and epistemic scripts perpetuate intersubjectivity through patterns of interactions. Interactive Learning Environments, 21(1),68-88. http://doi.org/10.1080/10494820.2010.547204.

Oxman AD, Guyatt GH (1988) .Guidelines for reading literature reviews. CMAJ 138: 697-703.

Pea, R. D. (2004). The social and technological dimensions of scaffolding and related theoretical concepts for learning, education, and human activity. Journal of the Learning Sciences, 13(3),423-451. http://doi.org/10.1207/s15327809j1s1303_6.

Ranjan B., Susmita B. (2010).A review of the causes of bullwhip effect in a supply chain.Int J Adv Manuf Technol.54:1245-1261 .DOI: 10.1007/s00170-010-2987-6.

Reiser, B. J. (2004). Scaffolding complex learning: The mechanisms of structuring and problematizing student work. Journal of the Learning Sciences, 13(3), 273-304. http://doi.org/10.1207/s15327809j1s1303_2.

Rembrandt Klopper,Sam Lubbe,Hemduth Rugbeer(2007).The Matrix Method of Literature Review. Alternation, 14(1), 262 - 276.

Ridley D (2008). The literature review: a step-bystep guide for students. London: SAGE.

Ronald H. Ballou, (2007).The evolution and future of logistics and supply chain management. European Business Review, 19(4). 332 - 348. http://dx.doi.org/10.1108/09555340710760152

Sabet, M. K., Tahriri, A., \& Pasand, P. G. (2013). The impact of peer scaffolding through process approach on EFL learners' academic writing fluency. Theory \& Practice in Language Studies, 3(10), 1893-1901. http://doi.org/10.4304/tpls.3.10.1893-1901.

Sarantakos(1998). Social Research. New York: Palgrave.

Simons, K. D., \& Ertmer, P. A. (2006). Scaffolding disciplined inquiry in problem-based learning environments. International Journal of Learning, 12(6), 297-305.

Swales, J. and Feak, C. (2012) Academic writing for graduate students. 3rd edn. Ann Arbor, Michigan: Michigan University Press.

Van de Pol, J., Volman, M., \& Beishuizen, J. (2010). Scaffolding in teacher-student interaction: A decade of research. Educational Psychology Review, 22(3), 271-296. http://doi.org/10.1007/s10648-010-9127-6.

Wagner CS, Roessner JD, Bobb K, Klein JT, Boyack KW, et al. (2011) Approaches to understanding and measuring interdisciplinary scientific research (IDR): a review of the literature.J Informetr 5: 14-26. doi:10.1016/j.joi.2010.06.004.

Webster, Jane \& Richard T Watson(2002). Analysing the Past to Prepare for the Future: Writing a Literature Review. MIS Quarterly 26:2.

Yongliang Xie,Yan Zhao, Wenxian Shi(2021).Research on Teaching Practice of Academic Literature Reading for Higher Vocational Students.Journal of Education and Practice.12(24), 5-14. 